Provided for non-commercial research and education use. Not for reproduction, distribution or commercial use.

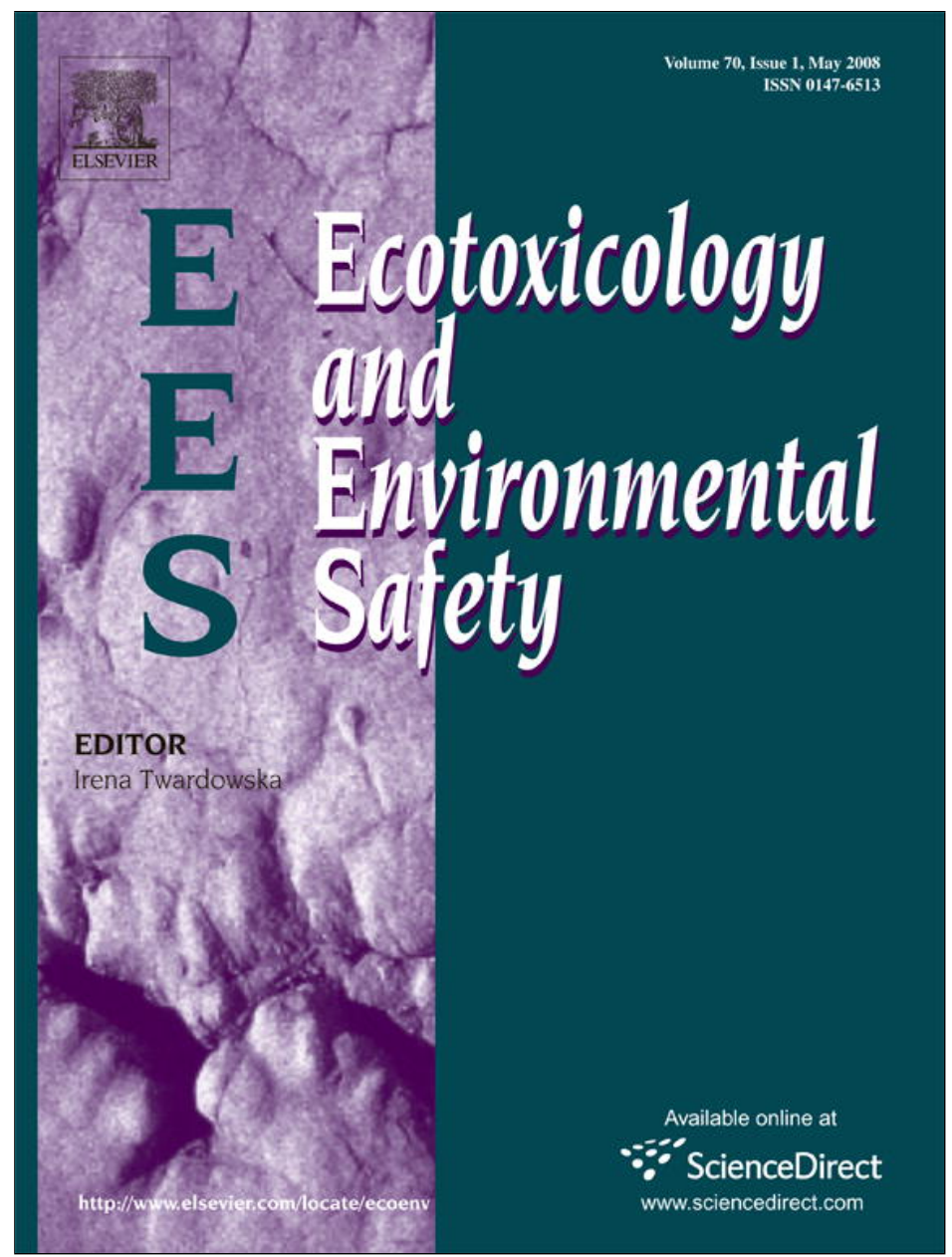

This article appeared in a journal published by Elsevier. The attached copy is furnished to the author for internal non-commercial research and education use, including for instruction at the authors institution and sharing with colleagues.

Other uses, including reproduction and distribution, or selling or licensing copies, or posting to personal, institutional or third party websites are prohibited.

In most cases authors are permitted to post their version of the article (e.g. in Word or Tex form) to their personal website or institutional repository. Authors requiring further information regarding Elsevier's archiving and manuscript policies are encouraged to visit:

http://www.elsevier.com/copyright 


\title{
Evaluation of Corophium orientale as bioindicator for Venice Lagoon: Sensitivity assessment and toxicity-score proposal ${ }^{\text {th }}$
}

\author{
Marco Picone $^{\mathrm{a}}$, Martina Bergamin ${ }^{\mathrm{b}}$, Arizzi Novelli Alessandra ${ }^{\mathrm{a}}$, Seta Noventa ${ }^{\mathrm{a}}$, \\ Eugenia Delaney ${ }^{\mathrm{b}}$, Andrea Barbanti ${ }^{\mathrm{b}}$, Annamaria Volpi Ghirardini ${ }^{\mathrm{a}, *}$ \\ ${ }^{a}$ Department of Environmental Sciences, University of Venice, Campo della Celestia 2737/b, I-30122 Venice, Italy \\ ${ }^{\mathrm{b}}$ Thetis S.p.A., Castello 2737/f, I-30122 Venice, Italy
}

Received 3 November 2005; received in revised form 3 June 2006; accepted 18 June 2006

Available online 13 February 2008

\begin{abstract}
The 96-h water-only exposure and 10-d sediment toxicity tests with the amphipod Corophium orientale were performed in order to enhance the knowledge about its overall sensitivity and its applicability to Venice Lagoon sediments. The values obtained with cadmium as reference toxicant demonstrated a certain variability of the $\mathrm{LC}_{50}$; the higher value was found in spring and the lower in late summer. Tests with other pure chemicals ( $\mathrm{Ni}$, Total Ammonia, Sodium Dodecyl-Sulphate) showed good discriminatory power; the toxicity gradient observed was: $\mathrm{Cd}\left(\mathrm{LC}_{50}\right.$ of $\left.3.3 \mathrm{mg} / \mathrm{L}\right)>\mathrm{SDS}\left(\mathrm{LC}_{50}\right.$ of $\left.8.7 \mathrm{mg} / \mathrm{L}\right)>$ total ammonia $\left(\mathrm{LC}_{50}\right.$ of $\left.126 \mathrm{mg} / \mathrm{L}\right)>\mathrm{Ni}(\mathrm{LC} 50$ of $352 \mathrm{mg} / \mathrm{L})$. Sediment toxicity test results were used to obtain information on non-treatment factors (grain-size, TOC content) that could act as confounding factors, and to develop a site-specific toxicity-score based on minimum significant difference approach. Confounding factors seem not to affect test results. The procedure to develop the toxicity score took into account the relatively lower sensitivity of C. orientale with respect to other amphipods commonly used in toxicity tests (Ampelisca abdita and Rhepoxynius abronius).

(C) 2006 Elsevier Inc. All rights reserved.
\end{abstract}

Keywords: Amphipods; Toxicity-score; Sediment toxicity test; Toxicity classes

\section{Introduction}

When using a battery of bioassays for sediment quality assessment, the use of sediment reworker species is recommended for the high ecological relevance of whole sediment testing. Sediment reworkers live in microhabitats beneath the sediment-water interface and are exposed to sediment-bound contaminants as well as pore-water and overlying water contaminants (USEPA, 1994; Ingersoll, 1995). The most suitable and reliable taxa for marine and estuarine sediments assessment are amphipods, echinoids, polychaetous annelids and bivalves (see Nendza, 2002, for an exhaustive list of species and standard methods available). Amphipods are the more widely and frequently

All the assays carried out with amphipods during the experimental period were performed in accordance with national and institutional guidelines for animal welfare and the protection of wildlife.

*Corresponding author. Fax: + 39415281494.

E-mail addresses: marco.picone@thetis.it (M. Picone),voghi@unive.it (A.V. Ghirardini) used test organisms for whole sediment testing, not only due to their worldwide distribution but also their: (a) short life cycle, which makes them suitable for chronic tests development (USEPA, 1992, 2001); (b) good discriminatory ability towards contaminated sediments and laboratory spiked-sediments with different organics and heavy metals (Erdem and Meadows, 1980; Bryant et al., 1985; Ciarelli et al., 1997; Bat and Raffaelli, 1998; Bat et al., 1998); (c) ease of maintaining a laboratory-culture.

Whole sediment tests with the amphipods Rhepoxynius abronius, Eohaustorius estuarius, Leptocheirus plumulosus, and Grandidierella japonica were reported by Ingersoll (1995) as being among the most widespread methods for assessing marine and estuarine sediment contamination. ICES (2003) suggests use of the amphipods Corophium sp., Ampelisca sp., Rhepoxynius sp., Leptocheirus sp., and Grandidierella sp. in monitoring programs.

Several standard methods and guidelines have been published for the 10-d mortality test with Atlantic and Pacific amphipod species, both in North America and 
Europe (Environment Canada, 1992, 1998; USEPA, 1994; PARCOM, 1995; RIKZ, 1999; ASTM, 2003). A number of test protocols, derived from standard guidelines and differing by some experimental conditions, were developed and applied by different authors (Bryant et al., 1985; Bat and Raffaelli, 1998; Bat et al., 1998). Recently ISO (2005) proposed an international standard for the determination of acute toxicity with Atlantic, Pacific and Mediterranean amphipod species.

In Italy, the most commonly used species in sediment quality assessment is Corophium orientale, a tube-building infaunal amphipod living in muddy or muddy-sand sediments of brackish and estuarine areas. Although it has often been used for the assessment of harbour and marine sediments toxicity (Onorati et al., 1999; Bigongiari et al., 2001), there is a lack of methodological studies concerning its sensitivity towards different classes of chemicals in wateronly exposure systems and, to the best of our knowledge, no data are available for spiked-sediments.

Within the framework of the ICSEL-Project (Integrazione delle Conoscenze sull'Ecosistema Lagunare), promoted by the Venice water authority (Magistrato alle Acque di Venezia) through its concessionaire Consorzio Venezia Nuova, the 10 -d sediment toxicity test with the endemic Mediterranean amphipod $C$. orientale is one of the bioassays chosen for toxicity assessment of sediments in the Venice Lagoon. C. orientale whole-sediment test was successfully applied to harbour sediments from the northern Tyrrhenian Sea (Onorati et al., 1999) and from harbour and deep sediments $(10$ and $150 \mathrm{~m})$ from the Ligurian, Tyrrhenian and Adriatic Seas (Bigongiari et al., 2001). This test is also routinely used for the assessment of coastal and marine sediments by different Italian Regional/Local Environmental Protection Agencies. This study was therefore done to improve knowledge on the overall sensitivity of $C$. orientale, in order to achieve the best possible accuracy in understanding sediment bioassays responses, taking into account (a) the relative sensitivity of this species with respect to other amphipods; (b) the possible effects of non-treatment factors. Water-only exposure tests were performed in order to elucidate the sensitivity of C. orientale towards chemicals characterised by different toxicity mechanisms: two heavy metals (cadmium, used as reference toxicant, and nickel), an organic (sodiumdodecyl-sulphate-SDS) and an inorganic compound (total ammonia, expressed as sum of ammonium ion and unionised ammonia). Cadmium is widely used as reference toxicant in water phase tests with amphipods (McGee et al., 1998; Onorati et al., 1999; Kater et al., 2000; Bigongiari et al., 2001) and its stability during 96-h exposure is well documented (Kater et al., 2000). Nickel was chosen because it is the metal first released into interstitial water when there is a surplus of metals over acid volatile sulphide (AVS) after oxidation that could occur in situ or during laboratory sediment tests (Di Toro et al., 1990; Berry et al., 1996). SDS is an anionic surfactant widely used as organic reference toxicant in water phase tests with amphipods and sea-urchins (Carr et al., 1996; Lera et al., 2004) due to its high water solubility. Ammonia is a well-known inorganic compound that is naturally present in sediments as by-product of nitrogen-rich organic matter and could also act as a confounding factor in sediment toxicity testing, causing "false positive" responses (Postma et al., 2002). Ammonia is proposed as reference toxicant by RIKZ (1999). In order to take into account the possible joint toxicity of unionised ammonia and ammonium ion proposed by several authors (Tabata, 1962; Armstrong et al., 1978; Arizzi Novelli et al., 2003), the data are reported as the sum of both compounds and referred to in the text as total ammonia.

Whole sediment toxicity tests were performed on shallow and channel sediments of the Venice Lagoon. All sampling sites were selected along a chemical pollution gradient and characterised by different grain size, TOC (total organic carbon) content, heavy metals and organic micropollutants concentrations on the basis of previous studies (MAV-CVN, 1999; Bocci et al., 2005; Carrer et al., 2005). Results from the whole sediment test were used to assess possible effects of non-treatment factors (grain-size and TOC), to evaluate applicability and discriminatory ability of the test protocol. The data were then used to develop a site specific toxicityscore for Venice Lagoon sediments, on the basis of the more recent and suitable statistical methods proposed in the literature to establish the threshold between presence and absence of toxicity (Thursby et al., 1997; Phillips et al., 2001). The score was conceived as a tool not only to distinguish between toxic and non-toxic samples, but also to classify test responses into different toxicity classes (absent, low, medium, high and extremely high toxicity). Following this design, the score could be a reliable tool to support decision-makers in regulatory and management frameworks, as the different toxicity classes could be associated with different remediation and/or management options. Very few examples of toxicityscores appear to be available in the literature, with most of the proposed methods being based on the authors' experience and use of simple statistical tests, as the $t$-test (Arizzi Novelli et al., 2001; Bigongiari et al., 2001; Onorati and Volpi Ghirardini, 2001). Instead, Bombardier and Bermingham (1999) proposed a classification system based on "toxicity incremental factors" (TIF), calculated by normalisation of the toxicity measured in toxicity units (TU) to a detectable limit for the method used.

\section{Materials and methods}

\subsection{Amphipods collection and holding}

Amphipods were purchased from CIBM (Consorzio Interuniversitario Biologia Marina) (Livorno, Italy). C. orientale specimens were sampled in the Magra River estuary (La Spezia, Italy) during the period from August 2003 to March 2004, following the procedure reported by Onorati et al. (1999). The sampling site is characterised by fine sediments and salinity generally $<20 \%$. Juveniles and young adults, passed through $1000-\mu \mathrm{m}$ and retained by $710-\mu \mathrm{m}$ mesh sieve, were selected for overnight shipment to the laboratory by express courier. During transport, the amphipods 
were maintained in a sealed plastic container filled with native sediment and sampling site water. In the laboratory, amphipods were gradually acclimatised to test conditions $\left(T=16 \pm 2{ }^{\circ} \mathrm{C}, S=35 \%\right.$ ), never increasing temperature and salinity by more than $2{ }^{\circ} \mathrm{C}$ and $5 \%$ per day, respectively (ISO, 2005). The culture was maintained under continuous light ( $>100$ lux) and aeration for a period not exceeding 10 days before testing (Bigongiari et al., 2001). Animals were not fed during holding.

\subsection{Chemicals}

Stock solutions of selected chemicals at $10,000 \mathrm{mg} / \mathrm{L}$ (for nickel and total ammonia) or $1000 \mathrm{mg} / \mathrm{L}$ (for cadmium and SDS) were obtained dissolving reagent grade salts $\left(\mathrm{CdCl}_{2} \cdot \mathrm{H}_{2} \mathrm{O}, \mathrm{NH}_{4} \mathrm{Cl}, \mathrm{Ni}\left(\mathrm{NO}_{3}\right)_{2} \cdot 6 \mathrm{H}_{2} \mathrm{O}\right.$, and SDS) in water purified with Milli- ${ }^{\circledR}$ System (Millipore, Bedford, MA, USA). Artificial seawater used as dilution water was composed of $\mathrm{NaCl}$, $\mathrm{MgSO}_{4} \cdot 7 \mathrm{H}_{2} \mathrm{O}, \mathrm{MgCl}_{2} \cdot 6 \mathrm{H}_{2} \mathrm{O}, \mathrm{KCl}, \mathrm{NaHCO}_{3}, \mathrm{KBr}, \mathrm{Na}_{2} \mathrm{CO}_{3}, \mathrm{H}_{3} \mathrm{BO}_{3}$, $\mathrm{SrCl}_{2} \cdot 6 \mathrm{H}_{2} \mathrm{O}, \mathrm{KF}, \mathrm{KI}$, and $\mathrm{CaCl}_{2} \cdot 2 \mathrm{H}_{2} \mathrm{O}$ (Ocean Fish, Prodac International, Cittadella, Italy). This commercial salt mixture had been successfully used in several studies with sea urchin gametes and embryos (Arizzi Novelli et al., 2002, 2003; Losso et al., 2004a).

\subsection{Toxicity testing: $96-h$ water-only exposure}

Water-only exposure tests were performed by exposure of amphipods to $500-\mathrm{mL}$ of test solution in a $1-\mathrm{L}$ glass beaker using at least five toxicant nominal concentrations and a negative control (artificial seawater) (Onorati et al., 1999; Bigongiari et al., 2001). Reference toxicant tests were done using the following concentrations of $\mathrm{Cd}: 0.8,1.6,3.2,6.4$, and $12.8 \mathrm{mg} / \mathrm{L}$ (Onorati et al., 1999). Test concentrations for pure chemical tests were: $80,160,240,320,400 \mathrm{mg} / \mathrm{L}$ for $\mathrm{Ni} ; 1,2,4,8$, and $16 \mathrm{mg} / \mathrm{L}$ for SDS; 25, 50, 100, 200, and $500 \mathrm{mg} / \mathrm{L}$ for total ammonia. All test concentrations were selected on the basis of preliminary range-finding tests. Nominal concentrations of ammonia were verified using the indophenol-blue method (Solarzano, 1969); measured concentrations were used for data analysis. Preliminary and definitive tests with ammonia were performed using artificial seawater buffered at $\mathrm{pH} 8.0 \pm 0.1$, in order to prevent biases due to the strong $\mathrm{pH}$-dependency of ammonia toxicity.

All tests were done at least in triplicate, with 20 amphipods per testchamber (Onorati et al., 1999). Temperature, salinity and $\mathrm{pH}$ were measured at the beginning and end of the test; during exposure, test chambers were continuously aerated and kept under constant illumination (>100 lux). All tests with pure substances (Ni, SDS, total ammonia) were performed with amphipods from the same batch in order to avoid biases due to possible seasonal changes in sensitivity.

\subsection{Toxicity testing: 10-d sediment toxicity test}

Sediments were sampled during summer-autumn 2003 in fifty-one stations distributed throughout the Lagoon of Venice (Fig. 1). Thirty-one surface sediment samples $(0-15 \mathrm{~cm}$ depth) were collected from the shallows using a $5-\mathrm{cm}$ diameter corer, following an integrated sampling design reported in detail in previous papers (Losso et al., 2004b; Volpi Ghirardini et al., 2005); twenty surface $(0-15 \mathrm{~cm})$ and ten deep $(30-45 \mathrm{~cm})$ sediment samples were collected from channels by scuba-divers using a $10-\mathrm{cm}$ diameter plastic-liner. The 10-d sediment toxicity tests were performed exposing amphipods to $200-\mathrm{mL}$ of 1 -mm dry-sieved wet sediment and 750$\mathrm{mL}$ of overlying water (artificial seawater) in 1-L wide mouth glass beakers, according to Onorati et al. (1999). The beakers were incubated under continuous aeration overnight at $T=16 \pm 2{ }^{\circ} \mathrm{C}$ and $S=35 \%$ in a thermostatic chamber before amphipods were added. Four replicates per sediment were tested, using 25 amphipods for each replicate (Bigongiari et al., 2001). A negative control using native sediment was added to each batch of test sediments. Water temperature, salinity, $\mathrm{pH}$, and $\mathrm{NH}_{3}$ were measured at the beginning and end of the test. Exposure was under continuous aeration, constant illumination ( $>100$ lux) and without water renewal (static test) (Bigongiari et al., 2001).

\subsection{Chemical analyses}

Dry-weight total-metals concentrations analyses were performed using inductively coupled plasma - atomic emission spectrometry (ICP-AES) for $\mathrm{Cu}, \mathrm{Cr}, \mathrm{Ni}$, and $\mathrm{Zn}$ (EPA method 6010B), atomic absorption-furnace technique for As, $\mathrm{Cd}$, and $\mathrm{Pb}$ (EPA methods 7060A, 7131B, and 7421, respectively) and atomic absorption spectrophotometry for $\mathrm{Hg}$ (EPA method 7473). Prior to analyses, samples were digested through microwave assisted acid digestion (EPA method 3052). SEM and AVS were determined on shallow sediments following the procedure by Allen et al. (1993).

\subsection{Data analyses}

For water-only exposure tests, data were analysed with Trimmed Spearman-Karber Method v1.5 for $\mathrm{LC}_{50}$ (lethal concentration 50) and $95 \%$ confidence limits calculation, whereas the EMSL Cincinnati-Dunnett v1.5 was used for NOEC (no observed effect concentration) and LOEC (lowest observed effect concentration) calculation, after arcsin square root transformation of raw data (USEPA, 1994, 2002). The 10-d sediment toxicity test results were reported as percentage of dead amphipods (PDA), normalised to control response using Abbott's formula (Finney, 1971). Oneside $t$-test $(\alpha=0.05)$ on raw data was used to check for statistical differences between samples and control. Normality and variance heterogeneity were checked using Shapiro-Wilk's test $(\alpha=0.01)$ and $F$-test $(\alpha=0.01)$, respectively. When the normality test failed, Wilcoxon rank-sum test was performed for testing means equality (USEPA, 2002).

\subsection{Toxicity-score development}

The first step towards the definition of a toxicity-score for $C$. orientale 10 -d sediment toxicity test was the designation of the most reliable threshold between toxicity and non-toxicity.

The toxicity threshold (TT) was defined using the minimum significance difference (MSD) criterion, proposed by Thursby et al. (1997) and Phillips et al. (2001). For every sample-control pair the MSD was calculated according to Eq. (1):

$\operatorname{MSD}=t_{(\alpha, n+m-2)} \cdot\left[\left(s_{1}^{2} / n\right)+\left(s_{2}^{2} / m\right)\right]^{1 / 2}$,

where $t$ is the $t$-value derived from standard tables, $\alpha$ the significance value, $n$ and $m$ the number of replicates for control and sample, $s_{1}^{2}$ and $s_{2}^{2}$ the variances for control and sample.

To report MSD values as proportion of control responses, the obtained MSD were divided by the respective negative control response, expressed in terms of "success" (survivors in sediment) (Phillips et al., 2001). These normalised MSD values were ranked in ascending order and the 90th percentile of the cumulative distribution was identified. The TT was then calculated by subtracting the 90 th percentile MSD value (expressed in \%) from 100:

Toxicity threshold $(\mathrm{TT})=100-90$ th percentile MSD $(\%)$.

To verify if a sample should be considered toxic or not, it is necessary to take into account the sample normalised response $(S)$ :

$S=100 \cdot[(\%$ success sample $) /(\%$ success control $)]$.

The $S$ value is compared with the toxicity limit (TL), defined as follows:

Toxicity limit $(\mathrm{TL})=$ control response $(\%) \mathrm{TT}$.

$\mathrm{TL}$ is the minimum sample response that could be regarded as significantly no different from the control. When $S>\mathrm{TL}$, the sample should be considered as non-toxic; when $S \leqslant \mathrm{TL}$, toxicity is statistically present. To develop a toxicity-score, detailed enough to distinguish between different pollution levels, 5 toxicity classes were chosen. Three more thresholds were established: (1) Medium toxicity threshold (MTT); (2) high toxicity threshold (HTT) and (3) extreme toxicity threshold (ETT). To take into account the relatively low sensitivity of the genus Corophium as compared with other infaunal amphipods (i.e. $R$. abronius) (Environment Canada, 1992; Bat and Raffaelli, 1998), MTT, HTT and ETT were calculated using 


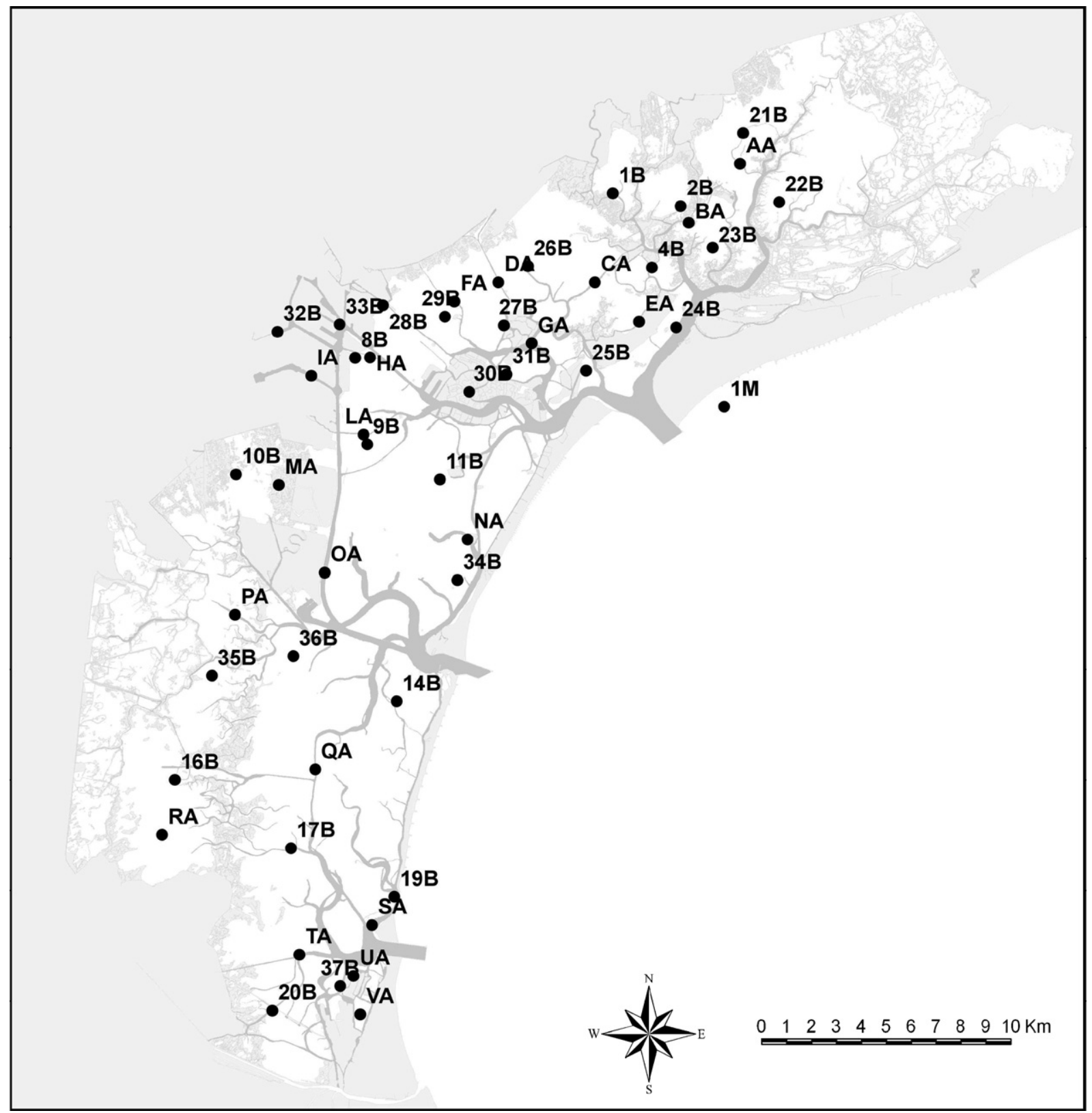

Fig. 1. Venice Lagoon map with sediment sampling sites.

three multiples of the 90th percentile selected in geometric progression with a common ratio of $1.5(1.5,3$, and 6$)$ in Eq. (2). The related toxicity limits were calculated by substituting TT with MTT, HTT, or ETT in Eq. (4):

Medium toxicity limit $(\mathrm{MTL})=$ control response $(\%)$ MTT,

High toxicity limit $(\mathrm{HTL})=$ control response $(\%)$ HTT,

Extreme toxicity limit $(\mathrm{ETL})=$ control response $(\%)$ ETT

\section{Results}

\subsection{Toxicity testing: 96- $h$ water-only exposure}

Fifteen tests were performed with $\mathrm{Cd}$ as reference toxicant, with a mean $\mathrm{LC}_{50} \pm \mathrm{SD}$ (standard deviation) of
$3.3 \pm 2.46 \mathrm{mg} / \mathrm{L} \mathrm{Cd}$. The highest $\mathrm{LC}_{50}$ value $(10.5 \mathrm{mg} / \mathrm{L} \mathrm{Cd})$ was found in March 2004, the lowest in September 2003 $(1.44 \mathrm{mg} / \mathrm{L} \mathrm{Cd})$. The $\mathrm{LC}_{50}$ 's obtained in the definitive test for $\mathrm{Ni}$, total ammonia and SDS were $352 \mathrm{mg} / \mathrm{L}, 126 \mathrm{mg} / \mathrm{L}$, and $8.7 \mathrm{mg} / \mathrm{L}$, respectively; the toxicity gradient for the chemicals tested was thus $\mathrm{Cd}>\mathrm{SDS}>$ total ammonia $>\mathrm{Ni}$. The NOEC, LOEC, and $\mathrm{LC}_{50}$ values with their $95 \%$ confidence limits for SDS, $\mathrm{Ni}$ and ammonia are reported in Table 1. The results regarding ammonia in the table are expressed both as total ammonia and unionised ammonia; unionised ammonia concentrations were calculated from test conditions $\left(\mathrm{pH}=8.0 ; S=35 ; T=16^{\circ} \mathrm{C}\right.$ ) using the Hampson model (Hampson, 1977), based on Whitfield's equations (Whitfield, 1974). The pH-values at the end of the tests with ammonia were within the range 8.0 \pm 0.2 . 
Table 1

$\mathrm{LC}_{50}$ with $95 \%$ confidence-limits, NOEC and LOEC values obtained with 96-h water-only exposure on pure substances

\begin{tabular}{lllll}
\hline Chemical & LC $_{50}$ & $95 \%$ C.L. & NOEC & LOEC \\
\hline SDS & 8.7 & $8.1-9.4$ & 2.0 & 4.0 \\
Total ammonia & 126 & $114-138$ & 51 & 95 \\
(Unionised ammonia) & $(2.78)$ & $(2.56-3.06)$ & $(1.13)$ & $(2.10)$ \\
Nickel & 352 & $325-382$ & 80 & 160 \\
\hline
\end{tabular}

All data are expressed in $\mathrm{mg} / \mathrm{L}$.

Negative controls with reconstituted seawater always had a mean survival percentage of $97.7 \pm 2.61 \%$ well within the acceptability criterion (survival $>85 \%$; Bigongiari et al., 2001; survival $>90 \%$, ISO, 2005).

\subsection{Toxicity testing: 10-d sediment toxicity tests}

Temperature, salinity, and $\mathrm{pH}$ were always within the acceptability limits $\left(T=16 \pm 2{ }^{\circ} \mathrm{C} ; S=35 \pm 4 ; \mathrm{pH}=8.0 \pm\right.$ 0.5) (PARCOM, 1995). Survival in controls with native sediment was always within the acceptability limits with a mean survival of $95.9 \pm 4.6 \% \quad(n=32$, c.v. $=4.8 \%)$. The results of the sediment toxicity tests are reported in Table 2 in terms of PDA, together with SD, $p$-values for one-side $t$-test, TOC content, grain-size analyses results, grain-size classification (Shepard, 1954), and toxicity classification following the score proposal. Survival success of the control $(S)$ is also reported. Sediment samples showed very different grain-size (from sand to silty-clay sediments) and TOC content (from 0.4 up to $15 \% \mathrm{C}$ ). However, there was little difference in toxicity among samples, with the exception of four samples exhibiting a PDA of above $20 \%$ (QA2, SG, 28B, and DA2).

\subsection{Toxicity-score development}

Using the 61 MSD's data for every sample-control pair, a 90th percentile of MSD's normalised value of $10 \%$ was obtained. The TT for $C$. orientale 10 -d sediment toxicity test is thus 90, and the toxicity limit is $90 \%$ of control survival, according to Eqs. (2) and (3). The values for the other toxicity limits are $85 \%, 70 \%$, and $40 \%$ of control survival for MTL, HTL, and ETL, respectively. The sediment samples were then classified in the different classes as follows: if $S<\mathrm{TL}(90 \%$ of control survival) toxicity is absent, if $85<S \leqslant 90 \%$ the toxicity is classified as low, if $85 \% \leqslant S<70 \%$ toxicity is medium, if $70 \% \leqslant S<$ $40 \%$ we are in presence of high toxicity, whereas if $S \leqslant 40 \%$ the toxicity is very high.

\section{Discussion}

\subsection{Toxicity testing: 96-h water-only exposure}

Test results showed that $C$. orientale sensitivity towards $\mathrm{Cd}$ varied during the testing period; the higher $\mathrm{LC}_{50}$ was found in early spring (March) and the lower during late summer (August-September). Up to $3 \times$ differences in $\mathrm{LC}_{50}$ could be considered as a normal variability observed during laboratory testing, but the differences measured during the whole testing period are generally higher (up to $7 \times)$ and the differences among the data obtained during summer-autumn and winter-spring are quite evident. The mean $\mathrm{LC}_{50}$ obtained with amphipods collected during late summer-autumn is $2.2 \pm 0.82 \mathrm{mg} / \mathrm{L}$ and the values ranged from 1.44 up to $3.97 \mathrm{mg} / \mathrm{L}$ (about $3 \times$ difference), whereas the mean value obtained during winter and early spring is $5.9 \pm 3.71 \mathrm{mg} / \mathrm{L}$ with a range of values from 1.9 up to $10.5 \mathrm{mg} / \mathrm{L}$ (more than $5 \times$ difference); the $\mathrm{LC}_{50}$ values were quite homogeneous and low during the period AugustOctober, whereas a significant increase in the mean and in the variance was registered from November to March. The one-way ANOVA $(\alpha=0.05)$ on log-transformed data showed that the difference between the means obtained in the two periods is basically different $(p=0.01)$. The variance obtained with summer-autumn tests (approx. $3 \times$ difference among LC $_{50}$ 's) can be due to normal laboratory variability, but for winter-spring tests results it seems that other factors should be taken into account. Although the available data are probably not sufficient (the data set covers a 8-months period only) and the statistical analysis is not conclusive to demonstrate an effective seasonal dependence of the sensitivity towards $\mathrm{Cd}$, they are consistent with the literature data reported for $C$. volutator (Kater et al., 2000) and C. orientale (Lera et al., 2004). Kater et al. (2001) reported a low sensitivity peak in C. volutator for Cd in April, and Ciarelli et al. (1997) found an identical trend for lindane-spiked sediments. Moreover, data collected with a different $C$. orientale population showed that specimens collected in summer had higher sensitivity than those sampled during spring, with $\mathrm{LC}_{50}$ differing by a factor of between 2 and 2.5 (Picone, unpublished data). The reasons for these seasonal variations in $C$. orientale sensitivity to cadmium are still unknown. In the literature, little is known about changes in cadmium toxicity towards field-collected marine and estuarine amphipods. McGee et al. (1998) found that size, reproductive status and molting cycle affected the acute toxicity of cadmium in field-collected Leptocheirus plumulosus. On the other hand, Kater et al. (2000) performed test with field-collected and laboratory-reared $C$. volutator and suggested that field temperature, photoperiod, size and reproduction cycle cannot be the sole causative factors of seasonal changes in cadmium toxicity. Ciarelli et al. (1997) found a lack of correlation between $C$. volutator size and $\mathrm{Cd}$ toxicity. Among the factors that could be involved, it seems that attention should focus on lipids content (Meador, 1993) and molting cycle (McGee et al., 1998); the latter is particularly interesting because of the enhanced uptake of cadmium in postmolt crustaceans reported by different authors (Wright and Frain, 1981; McGee et al., 1998). Data reported in the literature using the same population of $C$. orientale and the same test protocol with 
Table 2

Summary of the results for sediment toxicity test, grain-size, and TOC analysis results

\begin{tabular}{|c|c|c|c|c|c|c|c|c|c|c|c|c|c|}
\hline Sample & Typology & $\mathrm{PDA} \pm \mathrm{SD}$ & $p$-value & $\mathrm{S}$ & $\mathrm{C}$ & TL & $\begin{array}{l}\text { TOC } \\
(\%)\end{array}$ & $\begin{array}{l}\text { gravel } \\
(\%)\end{array}$ & $\begin{array}{l}\text { sand } \\
(\%)\end{array}$ & $\begin{array}{l}\text { silt } \\
(\%)\end{array}$ & $\begin{array}{l}\text { clay } \\
(\%)\end{array}$ & $\begin{array}{l}\text { Shepard sediment } \\
\text { classification }\end{array}$ & $\begin{array}{l}\text { Toxicity } \\
\text { judgment }\end{array}$ \\
\hline $1 \mathrm{~B}$ & $\mathrm{SH}(0-15 \mathrm{~cm})$ & $4 \pm 4.2$ & 0.095 & 96 & 91 & 82 & 0.45 & - & 28 & 48 & 24 & Loam & Absent \\
\hline $1 \mathrm{M}$ & $\mathrm{SH}(0-15 \mathrm{~cm})$ & $3 \pm 3.3$ & 0.084 & 97 & 99 & 89 & 0.41 & - & 68 & 27 & 4 & Silty-sand & Absent \\
\hline $2 \mathrm{~B}$ & $\mathrm{SH}(0-15 \mathrm{~cm})$ & $3 \pm 4.7$ & 0.139 & 97 & 99 & 89 & 1.50 & - & 4 & 62 & 35 & Clayey-silt & Absent \\
\hline $4 \mathrm{~B}$ & $\mathrm{SH}(0-15 \mathrm{~cm})$ & $1 \pm 2.3$ & 0.268 & 99 & 99 & 89 & 0.74 & - & 15 & 70 & 15 & Clayey-silt & Absent \\
\hline $8 \mathrm{~B}$ & $\mathrm{SH}(0-15 \mathrm{~cm})$ & $4 \pm 2.1$ & 0.095 & 96 & 95 & 86 & 1.60 & - & 33 & 38 & 29 & Loam & Absent \\
\hline $9 \mathrm{~B}$ & $\mathrm{SH}(0-15 \mathrm{~cm})$ & $5 \pm 2.4$ & 0.060 & 95 & 95 & 86 & 1.20 & - & 14 & 69 & 17 & Clayey-silt & Absent \\
\hline $10 \mathrm{~B}^{\mathrm{a}}$ & $\mathrm{SH}(0-15 \mathrm{~cm})$ & $0 \pm 2.4$ & $>0.05$ & 100 & 98 & 88 & 4.50 & - & 21 & 39 & 40 & Loam & Absent \\
\hline $11 \mathrm{~B}$ & $\mathrm{SH}(0-15 \mathrm{~cm})$ & $6 \pm 8.7$ & 0.130 & 94 & 95 & 86 & 1.50 & - & 9 & 57 & 34 & Clayey-silt & Absent \\
\hline 14B & $\mathrm{SH}(0-15 \mathrm{~cm})$ & $5 \pm 5.1$ & 0.060 & 95 & 98 & 88 & 0.86 & - & 47 & 42 & 10 & Silty-sand & Absent \\
\hline 16B & $\mathrm{SH}(0-15 \mathrm{~cm})$ & $10 \pm 8.8$ & 0.033 & 90 & 98 & 88 & 5.00 & - & 20 & 39 & 40 & Loam & Absent \\
\hline 17B & $\mathrm{SH}(0-15 \mathrm{~cm})$ & $4 \pm 4.7$ & 0.073 & 96 & 99 & 89 & 1.90 & - & 36 & 39 & 25 & Loam & Absent \\
\hline 19B & $\mathrm{SH}(0-15 \mathrm{~cm})$ & $4 \pm 5.3$ & 0.104 & 96 & 98 & 88 & 0.43 & - & 88 & 12 & - & Sand & Absent \\
\hline $20 \mathrm{~B}$ & $\mathrm{SH}(0-15 \mathrm{~cm})$ & $6 \pm 4.7$ & 0.030 & 94 & 98 & 88 & 0.96 & - & 54 & 31 & 16 & Silty-sand & Absent \\
\hline $21 \mathrm{~B}$ & $\mathrm{SH}(0-15 \mathrm{~cm})$ & $16 \pm 5.1$ & 0.001 & 84 & 91 & 82 & 1.60 & - & 8 & 42 & 50 & Silty-clay & Absent \\
\hline $22 \mathrm{~B}$ & $\mathrm{SH}(0-15 \mathrm{~cm})$ & $1 \pm 5.7$ & 0.383 & 99 & 91 & 82 & 0.87 & - & 4 & 73 & 22 & Clayey-silt & Absent \\
\hline $23 \mathrm{~B}$ & $\mathrm{SH}(0-15 \mathrm{~cm})$ & $7 \pm 4.2$ & 0.034 & 93 & 91 & 82 & 0.75 & - & 6 & 64 & 30 & Clayey-silt & Absent \\
\hline $24 \mathrm{~B}$ & $\mathrm{SH}(0-15 \mathrm{~cm})$ & $2 \pm 3.9$ & 0.195 & 98 & 99 & 89 & 0.47 & - & 60 & 30 & 10 & Silty-sand & Absent \\
\hline $25 \mathrm{~B}^{\mathrm{a}}$ & $\mathrm{SH}(0-15 \mathrm{~cm})$ & $0 \pm 2.0$ & $>0.05$ & 100 & 99 & 89 & 0.51 & - & 56 & 31 & 13 & Silty-sand & Absent \\
\hline $26 \mathrm{~B}$ & $\mathrm{SH}(0-15 \mathrm{~cm})$ & $0 \pm 2.5$ & 0.404 & 100 & 94 & 85 & 0.98 & - & 14 & 51 & 35 & Clayey-silt & Absent \\
\hline $27 \mathrm{~B}$ & $\mathrm{SH}(0-15 \mathrm{~cm})$ & $2 \pm 7.8$ & 0.352 & 98 & 94 & 85 & 1.30 & - & 26 & 58 & 16 & Sandy-silt & Absent \\
\hline $28 \mathrm{~B}$ & $\mathrm{SH}(0-15 \mathrm{~cm})$ & $33 \pm 19.1$ & 0.008 & 67 & 91 & 82 & 1.60 & - & 2 & 55 & 43 & Clayey-silt & Medium \\
\hline $29 \mathrm{~B}$ & $\mathrm{SH}(0-15 \mathrm{~cm})$ & $0 \pm 4.1$ & 0.500 & 101 & 94 & 85 & 1.00 & - & 17 & 50 & 33 & Clayey-silt & Absent \\
\hline 30B & $\mathrm{SH}(0-15 \mathrm{~cm})$ & $3 \pm 5.7$ & 0.178 & 97 & 99 & 89 & 1.90 & - & 22 & 44 & 34 & Loam & Absent \\
\hline $31 \mathrm{~B}$ & $\mathrm{SH}(0-15 \mathrm{~cm})$ & $5 \pm 4.1$ & 0.127 & 95 & 94 & 85 & 0.50 & - & 24 & 66 & 10 & Sandy-silt & Absent \\
\hline $32 \mathrm{~B}$ & $\mathrm{SH}(0-15 \mathrm{~cm})$ & $12 \pm 6.1$ & 0.005 & 88 & 99 & 89 & 2.40 & - & 46 & 25 & 29 & Loam & Low \\
\hline $33 \mathrm{~B}$ & $\mathrm{SH}(0-15 \mathrm{~cm})$ & $9 \pm 5.2$ & 0.009 & 91 & 99 & 89 & 1.60 & - & 32 & 34 & 34 & Loam & Absent \\
\hline 34B & $\mathrm{SH}(0-15 \mathrm{~cm})$ & $2 \pm 2.0$ & 0.104 & 98 & 99 & 89 & 0.91 & - & 45 & 38 & 18 & Silty-sand & Absent \\
\hline $35 \mathrm{~B}$ & $\mathrm{SH}(0-15 \mathrm{~cm})$ & $6 \pm 5.1$ & 0.034 & 94 & 99 & 89 & 15.00 & - & 17 & 56 & 27 & Clayey-silt & Absent \\
\hline 36B & $\mathrm{SH}(0-15 \mathrm{~cm})$ & $4 \pm 5.1$ & 0.095 & 96 & 99 & 89 & 1.70 & - & 47 & 33 & 20 & Silty-sand & Absent \\
\hline 37B & $\mathrm{SH}(0-15 \mathrm{~cm})$ & $5 \pm 6.1$ & 0.085 & 95 & 98 & 88 & 2.40 & - & 34 & 38 & 29 & Loam & Absent \\
\hline SG & $\mathrm{SH}(0-15 \mathrm{~cm})$ & $29 \pm 8.7$ & 0.001 & 71 & 95 & 86 & 2.8 & - & 3 & 61 & 36 & Clayey-silt & Medium \\
\hline AA1 & $\mathrm{CH}(0-15 \mathrm{~cm})$ & $14 \pm 7.5$ & 0.008 & 86 & 98 & 88 & 0.95 & 1 & 6 & 63 & 30 & Clayey-silt & Low \\
\hline BA1 & $\mathrm{CH}(0-15 \mathrm{~cm})$ & $11 \pm 3.9$ & 0.004 & 89 & 98 & 88 & 0.56 & 1 & 60 & 28 & 11 & Silty-sand & Absent \\
\hline CA1 & $\mathrm{CH}(0-15 \mathrm{~cm})$ & $10 \pm 10.5$ & 0.069 & 90 & 93 & 84 & 0.67 & - & 14 & 45 & 41 & Clayey-silt & Absent \\
\hline DA1 & $\mathrm{CH}(0-15 \mathrm{~cm})$ & $9 \pm 2.5$ & 0.035 & 91 & 94 & 85 & 0.51 & - & 43 & 38 & 19 & Silty-sand & Absent \\
\hline EA1 & $\mathrm{CH}(0-15 \mathrm{~cm})$ & $16 \pm 5.3$ & 0.001 & 84 & 98 & 88 & 0.77 & - & 4 & 74 & 22 & Clayey-silt & Low \\
\hline FAl & $\mathrm{CH}(0-15 \mathrm{~cm})$ & $5 \pm 4.1$ & 0.127 & 95 & 94 & 85 & 1.86 & 3 & 3 & 50 & 44 & Clayey-silt & Absent \\
\hline GA1 & $\mathrm{CH}(0-15 \mathrm{~cm})$ & $3 \pm 4.1$ & 0.239 & 97 & 94 & 85 & 0.44 & - & 39 & 49 & 15 & Sandy-silt & Absent \\
\hline HAl & $\mathrm{CH}(0-15 \mathrm{~cm})$ & $0 \pm 4.2$ & 0.500 & 100 & 91 & 82 & 0.42 & - & 72 & 16 & 12 & Silty-sand & Absent \\
\hline IA 1 & $\mathrm{CH}(0-15 \mathrm{~cm})$ & $1 \pm 8.4$ & 0.412 & 99 & 91 & 82 & 1.21 & - & 3 & 62 & 35 & Clayey-silt & Absent \\
\hline LA1 & $\mathrm{CH}(0-15 \mathrm{~cm})$ & $18 \pm 6.6$ & 0.002 & 82 & 91 & 82 & 1.68 & 28 & 20 & 27 & 25 & Loam & Low \\
\hline MA1 & $\mathrm{CH}(0-15 \mathrm{~cm})$ & $12 \pm 6.2$ & 0.009 & 88 & 91 & 82 & 2.90 & - & 4 & 60 & 36 & Clayey-silt & Absent \\
\hline NA1 & $\mathrm{CH}(0-15 \mathrm{~cm})$ & $1 \pm 3.5$ & 0.352 & 99 & 93 & 84 & 1.24 & - & 3 & 65 & 32 & Clayey-silt & Absent \\
\hline OA1 & $\mathrm{CH}(0-15 \mathrm{~cm})$ & $1 \pm 6.1$ & 0.390 & 99 & 93 & 84 & 0.69 & 3 & 83 & 8 & 6 & Sand & Absent \\
\hline PA1 & $\mathrm{CH}(0-15 \mathrm{~cm})$ & $0 \pm 3.4$ & 0.375 & 101 & 95 & 86 & 0.82 & 7 & 34 & 37 & 22 & Loam & Absent \\
\hline QA1 & $\mathrm{CH}(0-15 \mathrm{~cm})$ & $2 \pm 6.3$ & 0.314 & 98 & 95 & 86 & 3.42 & - & 3 & 64 & 33 & Clayey-silt & Absent \\
\hline RA1 & $\mathrm{CH}(0-15 \mathrm{~cm})$ & $9 \pm 7.3$ & 0.040 & 91 & 95 & 86 & 14.21 & - & 2 & 50 & 48 & Clayey-silt & Absent \\
\hline SA1 & $\mathrm{CH}(0-15 \mathrm{~cm})$ & $2 \pm 5.8$ & 0.268 & 98 & 98 & 88 & 0.58 & 11 & 72 & 11 & 6 & Sand & Absent \\
\hline $\mathrm{TA}^{\mathrm{a}}$ & $\mathrm{CH}(0-15 \mathrm{~cm})$ & $0 \pm 2.4$ & $>0.05$ & 100 & 98 & 88 & 1.61 & 20 & 38 & 27 & 15 & Loam & Absent \\
\hline $\mathrm{UA}^{\mathrm{a}}$ & $\mathrm{CH}(0-15 \mathrm{~cm})$ & $8 \pm 4.1$ & $>0.05$ & 92 & 98 & 88 & 1.74 & 8 & 40 & 30 & 22 & Loam & Absent \\
\hline VAl & $\mathrm{CH}(0-15 \mathrm{~cm})$ & $7 \pm 7.7$ & 0.064 & 93 & 98 & 88 & 2.23 & 16 & 21 & 37 & 26 & Loam & Absent \\
\hline BA2 & $\mathrm{CH}(30-45 \mathrm{~cm})$ & $12 \pm 5.3$ & 0.005 & 88 & 98 & 88 & 0.73 & 5 & 62 & 22 & 11 & Silty-sand & Low \\
\hline DA2 & $\mathrm{CH}(30-45 \mathrm{~cm})$ & $62 \pm 17.4$ & 0.0003 & 38 & 94 & 85 & 1.11 & - & 15 & 50 & 35 & Clayey-silt & Extreme \\
\hline EA2 & $\mathrm{CH}(30-45 \mathrm{~cm})$ & $10 \pm 7.5$ & 0.027 & 90 & 98 & 88 & 0.90 & - & 3 & 71 & 26 & Clayey-silt & Absent \\
\hline FA2 & $\mathrm{CH}(30-45 \mathrm{~cm})$ & $11 \pm 8.5$ & 0.054 & 89 & 94 & 85 & 1.68 & - & 2 & 50 & 48 & Clayey-silt & Absent \\
\hline MA2 & $\mathrm{CH}(30-45 \mathrm{~cm})$ & $13 \pm 2.2$ & 0.001 & 87 & 91 & 82 & 3.01 & - & 7 & 58 & 35 & Clayey-silt & Absent \\
\hline NA2 & $\mathrm{CH}(30-45 \mathrm{~cm})$ & $6 \pm 2.2$ & 0.016 & 94 & 93 & 84 & 1.23 & - & 5 & 81 & 14 & Clayey-silt & Absent \\
\hline $\mathrm{OA} 2$ & $\mathrm{CH}(30-45 \mathrm{~cm})$ & $0 \pm 6.5$ & 0.500 & 100 & 93 & 84 & 0.64 & 2 & 69 & 18 & 11 & Silty-sand & Absent \\
\hline QA2 & $\mathrm{CH}(30-45 \mathrm{~cm})$ & $27 \pm 8.0$ & 0.001 & 73 & 95 & 86 & 4.02 & - & 4 & 61 & 35 & Clayey-silt & Medium \\
\hline $\mathrm{RA} 2^{\mathrm{b}}$ & $\mathrm{CH}(30-45 \mathrm{~cm})$ & $7 \pm 6.0$ & 0.057 & 93 & 95 & 86 & 32.52 & 46 & 30 & 10 & 14 & - & Absent \\
\hline TA2 & $\mathrm{CH}(30-45 \mathrm{~cm})$ & $4 \pm 5.3$ & 0.104 & 96 & 98 & 88 & 1.21 & - & 85 & 8 & 7 & Sand & Absent \\
\hline
\end{tabular}

$\mathrm{SH}=$ Shallow, $\mathrm{CH}=$ Channel.

Toxicity test results are reported in terms of percentage of dead amphipods (PDA) together with standard deviation, $p$-values for $t$-test and survival adjusted to control (S), control survival (C), and Toxicity Limit (TL).

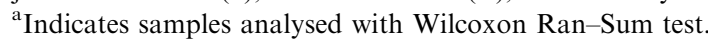

${ }^{\mathrm{b}}$ For sample RA2 grain-size classification after Shepard (1954) was not performed due the high amount of gravel. 
$\mathrm{Cd}$ are in good agreement with those obtained in this study (Onorati et al., 1999; Bigongiari et al., 2001; Lera et al., 2004). These data highlighted that $C$. orientale is a lowmedium sensitivity amphipod when compared with other species commonly used for ecotoxicological surveys (Table 3), and tests performed with total ammonia confirmed this observation (Table 3). Indeed, when tested under comparable conditions, $C$. orientale seems to have similar sensitivity to C. volutator and G. japonica (both amphipods of the Corophiidae family), but it is usually less sensitive than $A$. abdita and $R$. abronius (USEPA, 1992; Kohn et al., 1994). Data reported by Environment Canada (1998) again showed the higher sensitivity of $R$. abronius ( $\mathrm{LC}_{50}$ of $65 \mathrm{mg} / \mathrm{L}$ of $\mathrm{NH}_{3}-\mathrm{N}$ ) compared to $C$. orientale, and a relatively similar or rather lower sensitivity of Eohaustorius washingtonianus and E. estuarius $\left(\mathrm{LC}_{50}\right.$ of $139 \mathrm{mg} / \mathrm{L}$ of $\mathrm{NH}_{3}-\mathrm{N}$ and $156 \mathrm{mg} / \mathrm{L}$ of $\mathrm{NH}_{3}-\mathrm{N}$, respectively). Regarding ammonia, a direct comparison with $C$. volutator, an amphipod alike $C$. orientale morphologically and phylogenically is not possible, because the data obtained by Postma et al. (2002) ( $\mathrm{LC}_{50}$ of $115 \mathrm{mg} / \mathrm{L}$ at $\mathrm{pH} 8.0$ ) were with shorter exposure (72-h). The high LOEC and $\mathrm{LC}_{50}$ suggest that, although the data were obtained during a 96-h water-only exposure, Corophium is quite tolerant of ammonia but, when testing Venice Lagoon sediments, ammonia would probably not be a concern. Total

Table 3

Reference toxicant $(\mathrm{Cd})$ and ammonia $96-\mathrm{h} \mathrm{LC}_{50}$ with $95 \%$ confidence limits reported in literature for amphipods used in bioassays

\begin{tabular}{lcclll}
\hline Specie & \multicolumn{2}{l}{$\mathrm{Cd}$} & \multicolumn{3}{l}{ Ammonia } \\
\cline { 2 - 3 } \cline { 5 - 6 } \cline { 5 - 6 } C. orientale & $3.3^{\mathrm{a}}$ & $0.87-5.80$ & & $125.7(2.78)^{\mathrm{a}}$ & $114.3-138.3(2.56-3.06)$ \\
& $2.91^{\mathrm{b}}$ & $2.09-3.73$ & & \\
& $4.2^{\mathrm{b}}$ & $2.96-5.63$ & & \\
A. abdita & $0.33^{\mathrm{c}}$ & $0.29-0.38$ & & $49.8(0.83)^{\mathrm{d}}$ & $45.6-54.4(0.76-0.92)$ \\
& $0.94^{\mathrm{d}}$ & $0.83-1.05$ & & \\
& $1.32^{\mathrm{d}}$ & $1.22-1.43$ & & \\
& $1.09^{\mathrm{e}}$ & - & & & \\
E. estuarius & $9.33^{\mathrm{c}}$ & $7.20-12.09$ & & $126.7(2.52)^{\mathrm{d}}$ & $114.2-168.4(2.26-3.38)$ \\
& $6.42^{\mathrm{e}}$ & $4.90-8.30$ & & \\
& $11.41^{\mathrm{e}}$ & $8.90-14.70$ & & \\
G. japonica & $1.17^{\mathrm{c}}$ & $0.94-1.46$ & & $154.7(3.48)$ & $133.4-203.8(3.05-4.46)$ \\
& $3.14^{\mathrm{d}}$ & $2.36-4.17$ & & \\
R. abronius & $0.92^{\mathrm{c}}$ & $0.68-1.25$ & & $78.7(1.59)^{\mathrm{d}}$ & $73.3-84.5(1.46-1.72)$ \\
& $1.92^{\mathrm{d}}$ & $1.47-2.51$ & & \\
& $0.79^{\mathrm{e}}$ & $0.5-1.1$ & &
\end{tabular}

Data are expressed in $\mathrm{mg} / \mathrm{L}$ of $\mathrm{Cd}$.

All data are reported in $\mathrm{mg} / \mathrm{L}$. For ammonia, number within brackets represents the values for the unionised form.

${ }^{\text {a }}$ Present work.

${ }^{\mathrm{b}}$ Onorati et al. (1999).

cASTM (2003).

${ }^{\mathrm{d}}$ Kohn et al. (1994).

${ }^{\mathrm{e}}$ USEPA (1992). 95\% C.L. for data with Cd obtained in this work represent mean $\pm \mathrm{SD}$ obtained during the experimental period. ammonia concentrations in pore waters could reach values as high as $100 \mathrm{mg} / \mathrm{L}$ only in sites near the industrial area, whereas pore-water concentrations in the open Lagoon are generally much lower (Volpi Ghirardini, unpublished data, MAV-CVN, 2003). Moreover, when remaining buried in sediments Corophium sp. is not exposed directly to porewater, but maintains a breathing current through its tube and so causes a dilution of the pore-water with the overlying water. However, Moore et al. (1997) reported a $\mathrm{LC}_{50}$ of $98.8 \mathrm{mg} / \mathrm{L}$ of $\mathrm{NH}_{3}-\mathrm{N}$ for L. plumulosus (measured in the pore-water) in a 10-d toxicity test on sediment spiked with $\mathrm{NH}_{4} \mathrm{Cl}$; this value is not very different from the $96-\mathrm{h}$ water only $\mathrm{LC}_{50}\left(88.9 \mathrm{mg} / \mathrm{L}\right.$ of $\left.\mathrm{NH}_{3}-\mathrm{N}\right)$ found by the same authors. Equally, Environment Canada (1998) reported small differences between $10-\mathrm{d}$ pore-water $\mathrm{LC}_{50}$ and $96-\mathrm{h}$ water only $\mathrm{LC}_{50}$ for both $R$. abronius $\left(65 \mathrm{mg} / \mathrm{L}\right.$ of $\mathrm{NH}_{3}-\mathrm{N}$ and $57.7 \mathrm{mg} / \mathrm{L}$ of $\mathrm{NH}_{3}-\mathrm{N}$, respectively) and E. washingtonianus $\left(139 \mathrm{mg} / \mathrm{L}\right.$ of $\mathrm{NH}_{3}-\mathrm{N}$ and $112 \mathrm{mg} / \mathrm{L}$ of $\left.\mathrm{NH}_{3}-\mathrm{N}\right)$, whereas a marked difference was highlighted for Amphiporeia virginiana $\left(151 \mathrm{mg} / \mathrm{L}\right.$ of $\mathrm{NH}_{3}-\mathrm{N}$ and $24.6 \mathrm{mg} / \mathrm{L}$ of $\mathrm{NH}_{3}-\mathrm{N}$ ). As regards nickel, $C$. orientale seems to be at least one order of magnitude less sensitive than $C$. volutator, although the data reported by Bryant et al. (1985) ( $\mathrm{LC}_{50}$ of $34 \mathrm{mg} / \mathrm{L}$ ) were obtained using different experimental conditions (thin layer of sediment in test chambers). Literature data on Ni toxicity towards other amphipods are in agreement with the data reported by Bryant et al. (1985) and Ewell et al. (1986) found an $\mathrm{LC}_{50}$ for Gammarus fasciatus of about $50 \mathrm{mg} / \mathrm{L}$, whereas Rehwoldt et al. (1973) reported $\mathrm{LC}_{50}$ values ranging from 13 up to $15.2 \mathrm{mg} / \mathrm{L}$ for Gammarus sp. Similar results were obtained by Gajbhiye and Hirota (1990) with the shrimp Artemia sp. $\left(\mathrm{LC}_{50}\right.$ of $11.2-15.6 \mathrm{mg} / \mathrm{L}$ ). Data obtained in this work for $C$. orientale showed that nickel is about 100 times less toxic than cadmium, confirming that its contribution to toxicity could generally be considered negligible as compared with other metals. However, with increasing nickel concentrations (above $160 \mathrm{mg} / \mathrm{L}$ ), an increasing number of the surviving amphipods showed a strongly limited motility (with only pereiopods and gnathopods exhibiting small movements after mechanical stimulation), highlighting a marked sub-lethal effect of nickel on $C$. orientale.

The $\mathrm{LC}_{50}$ for SDS is consistent with the data reported by Lera et al. (2004) using two populations of $C$. orientale $\left(\mathrm{LC}_{50}\right.$ ranging from approx. 4 up to $12 \mathrm{mg} / \mathrm{L}$ ) and in agreement with the $\mathrm{LC}_{50}$ range $(5.16-9.56 \mathrm{mg} / \mathrm{L}$ ) found by Carr et al. (1996) for A. abdita.

\subsection{Toxicity testing: $10-d$ sediment toxicity test}

Of the 61 samples tested, 21 were statistically different from the control when using one-side $t$-test or Wilcoxon rank-sum test. The sediments giving a not statistically different response from the control ranged from silty-clay to sands, with all the main grain-size classes of the Lagoon (silty-sands, loams, sandy-silts, clayey-silts) being well represented in this "no-effect" class. 
Furthermore, samples not statistically different from the control had a TOC content ranging from $0.4 \%$ to $4.5 \%$. These results lead to the conclusion that grain-size and TOC are not an issue when testing Venice Lagoon sediments with $C$. orientale. This lack of evidence of noncontaminant factors contribution to the toxicity is a key element to establish the applicability of the method in an extremely heterogeneous environment such as the Venice Lagoon. The tolerance of $C$. orientale to a very wide range of grain-size thus makes it a powerful tool for toxicity assessment over the whole Lagoon.

Samples from the shallows generally resulted as not toxic for $C$. orientale following the toxicity-score proposed in this paper: $90 \%$ of samples showed an absence of toxicity, whereas only 1 sample exhibited low toxicity (32B) and 2 were classified as medium toxicity sediments (SG and 28B). These results are not surprising due to the fact that these samples are located in or close to the industrial area of Porto Marghera, the most contaminated area of the Lagoon, where metals and organic pollutants (PAH, PCDD $/ F$, and PCBs) are up to 2 order of magnitude higher than in the less contaminated areas (MAV-CVN, 1999). However, not all the samples from this area evidenced toxicity (i.e. site 33B) and although the measured concentration of metals were higher than in the whole lagoon (Table 4), the difference SEM-AVS was less than 0 for all the sample toxic towards the amphipods, excluding effects due to $\mathrm{Cd}, \mathrm{Cu}, \mathrm{Ni}, \mathrm{Pb}$ and $\mathrm{Zn}$ (Table 5). The toxicity is probably due to other pollutants (i.e. $\mathrm{Hg}$ and organic micropollutants).

In general, channel sediments showed a more heterogeneous state than shallows: 17 surface sediments $(85 \%)$ were not toxic, whereas 3 samples located in the northern lagoon (AA1 and EA1) and near the industrial area (LA1) showed low toxicity. As regards deep sediments, BA2 exhibited low toxicity, QA2 showed medium toxicity, whereas DA2 was extremely toxic towards $C$. orientale.

There was a generally good agreement between surface and deep sediments toxicity responses, with the exceptions of site EA, where surface sediments were slightly more toxic than deeper ones, and sites BA, QA, and DA, where deeper sediments were more toxic than surface ones. In QA and DA sites the difference in toxicity response was quite marked, deeper sediments being much more toxic. The available chemical data showed no marked difference in sediment contamination between surface and deep samples nor among shallows and channels (Table 4).

The toxicity-score proved to be a valuable tool for sediment toxicity classification as it could distinguish industrial area samples from open lagoon sites. However, although it was possible to identify statistically toxic sediments using the score, and even if the $C$. orientale sediment test was reported as able to discriminate between harbour sediments from the Tyrrhenian coast (Onorati et al., 1999), there is still concern over the real discriminatory ability of $C$. orientale when testing Venice Lagoon sediments. Indeed, the "absolute" differences in mortality
Table 4

Total metal concentrations ( $\mathrm{mg} / \mathrm{kg}$ dry weight) in shallows and channels

\begin{tabular}{|c|c|c|c|c|c|c|c|c|}
\hline Site & As & $\mathrm{Cd}$ & $\mathrm{Cr}$ & $\mathrm{Cu}$ & $\mathrm{Hg}$ & $\mathrm{Ni}$ & $\mathrm{Pb}$ & $\mathrm{Zn}$ \\
\hline $1 \mathrm{M}$ & 17.2 & 0.24 & 18 & 8 & 1.04 & 9 & 8 & 35 \\
\hline $1 \mathrm{~B}$ & 7.4 & 0.12 & 33 & 16 & 0.35 & 15 & 27 & 63 \\
\hline $2 \mathrm{~B}$ & 7.9 & 0.45 & 50 & 23 & 0.94 & 25 & 31 & 79 \\
\hline $4 B$ & 9.0 & 0.35 & 29 & 24 & 0.51 & 20 & 25 & 84 \\
\hline $8 B$ & 16.6 & 2.81 & 45 & 54 & 1.69 & 19 & 37 & 429 \\
\hline $9 \mathrm{~B}$ & 12.3 & 1.69 & 47 & 32 & 1.12 & 21 & 42 & 208 \\
\hline $10 \mathrm{~B}$ & 24.5 & 2.43 & 65 & 43 & 0.60 & 35 & 37 & 265 \\
\hline $11 \mathrm{~B}$ & 7.7 & 0.82 & 51 & 24 & 0.98 & 18 & 35 & 82 \\
\hline $14 B$ & 7.1 & 0.24 & 48 & 13 & 0.29 & 17 & 15 & 66 \\
\hline $16 \mathrm{~B}$ & 15.9 & 0.80 & 64 & 24 & 0.27 & 38 & 34 & 120 \\
\hline 17B & 10.2 & 0.52 & 53 & 19 & 0.40 & 26 & 22 & 90 \\
\hline 19B & 4.5 & 0.23 & 66 & 4 & 0.14 & 15 & 11 & 50 \\
\hline $20 \mathrm{~B}$ & 7.3 & 0.27 & 52 & 15 & 0.13 & 22 & 23 & 88 \\
\hline $21 \mathrm{~B}$ & 6.1 & 0.27 & 45 & 22 & 0.20 & 24 & 29 & 63 \\
\hline $22 B$ & 6.9 & 0.21 & 38 & 15 & 0.93 & 19 & 25 & 70 \\
\hline $23 \mathrm{~B}$ & 6.0 & 0.25 & 50 & 20 & 0.66 & 26 & 25 & 73 \\
\hline $24 B$ & 5.4 & 0.20 & 28 & 13 & 0.20 & 14 & 12 & 38 \\
\hline $25 B$ & 5.5 & 0.21 & 34 & 10 & 0.45 & 12 & 18 & 59 \\
\hline $26 \mathrm{~B}$ & 9.3 & 0.42 & 40 & 19 & 0.07 & 24 & 25 & 120 \\
\hline $27 \mathrm{~B}$ & 7.0 & 0.77 & 27 & 25 & 0.77 & 14 & 31 & 110 \\
\hline $28 \mathrm{~B}$ & 14.5 & 5.66 & 47 & 55 & 1.39 & 22 & 50 & 1072 \\
\hline 29B & 8.9 & 1.45 & 42 & 22 & 0.67 & 27 & 37 & 129 \\
\hline $30 \mathrm{~B}$ & 10.1 & 2.58 & 45 & 106 & 2.00 & 21 & 49 & 310 \\
\hline $31 \mathrm{~B}$ & 4.4 & 0.66 & 28 & 18 & 0.57 & 11 & 22 & 91 \\
\hline $32 B$ & 13.9 & 1.87 & 144 & 97 & 3.28 & 115 & 65 & 375 \\
\hline $33 \mathrm{~B}$ & 23.8 & 7.06 & 54 & 86 & 3.66 & 19 & 78 & 830 \\
\hline $34 \mathrm{~B}$ & 6.6 & 0.33 & 37 & 13 & 0.91 & 15 & 16 & 70 \\
\hline $35 \mathrm{~B}$ & 15.2 & 0.57 & 36 & 17 & 0.31 & 19 & 26 & 89 \\
\hline $36 \mathrm{~B}$ & 10.6 & 0.34 & 62 & 16 & 0.15 & 28 & 22 & 92 \\
\hline 37B & 8.8 & 0.52 & 88 & 24 & 0.37 & 44 & 28 & 114 \\
\hline $\mathrm{SG}$ & 9.0 & 4.00 & 65 & 93 & 1.97 & 20 & 60 & 736 \\
\hline AAl & 7.1 & 0.69 & 44 & 22 & 1.10 & 20 & 19 & 55 \\
\hline BA1 & 6.7 & 0.52 & 27 & 25 & 0.25 & 13 & 12 & 35 \\
\hline CA1 & 5.8 & 0.26 & 35 & 14 & 0.52 & 15 & 15 & 63 \\
\hline DA1 & 10.3 & 1.06 & 36 & 23 & 0.34 & 16 & 27 & 132 \\
\hline EA1 & 8.4 & 0.54 & 35 & 30 & 0.83 & 19 & 32 & 108 \\
\hline FA1 & 14.8 & 1.56 & 54 & 50 & 0.98 & 28 & 53 & 289 \\
\hline GA1 & 6.0 & 0.72 & 35 & 21 & 0.43 & 23 & 42 & 81 \\
\hline NA1 & 7.3 & 0.43 & 44 & 22 & 1.09 & 18 & 22 & 87 \\
\hline OA1 & 4.9 & 0.27 & 16 & 13 & 0.09 & 22 & 11 & 51 \\
\hline PA1 & 9.7 & 0.95 & 36 & 26 & 0.75 & 18 & 52 & 213 \\
\hline QA1 & 12.4 & 0.81 & 52 & 30 & 0.65 & 30 & 31 & 153 \\
\hline RA1 & 12.3 & 0.57 & 23 & 14 & 0.12 & 14 & 15 & 111 \\
\hline GA1 & 6.0 & 0.72 & 35 & 21 & 0.43 & 23 & 42 & 81 \\
\hline HA1 & 6.5 & 1.54 & 21 & 20 & 0.62 & 10 & 22 & 163 \\
\hline IA1 & 12.7 & 1.58 & 50 & 42 & 1.34 & 22 & 43 & 238 \\
\hline LA1 & 84.1 & 14.41 & 292 & 80 & 1.43 & 131 & 289 & 1055 \\
\hline MA1 & 13.4 & 1.57 & 52 & 32 & 0.68 & 24 & 33 & 197 \\
\hline SA1 & 5.7 & 0.30 & 52 & 15 & 0.10 & 24 & 11 & 29 \\
\hline TA1 & 10.2 & 0.75 & 55 & 18 & 0.22 & 31 & 24 & 71 \\
\hline UA1 & 9.2 & 0.56 & 80 & 53 & 0.28 & 40 & 36 & 140 \\
\hline VA1 & 10.3 & 1.03 & 77 & 57 & 0.35 & 36 & 37 & 135 \\
\hline BA2 & 7.3 & 0.32 & 23 & 14 & 0.42 & 13 & 12 & 31 \\
\hline DA2 & 13.5 & 1.36 & 48 & 40 & 0.81 & 25 & 41 & 171 \\
\hline EA2 & 8.7 & 0.57 & 36 & 34 & 1.17 & 19 & 42 & 89 \\
\hline FA2 & 14.9 & 2.35 & 56 & 55 & 1.38 & 30 & 58 & 375 \\
\hline NA2 & 8.0 & 0.54 & 47 & 23 & 0.99 & 20 & 25 & 111 \\
\hline OA2 & 6.0 & 0.45 & 21 & 12 & 0.09 & 17 & 11 & 46 \\
\hline QA2 & 12.6 & 0.86 & 55 & 28 & 0.81 & 31 & 33 & 154 \\
\hline RA2 & 3.2 & 0.13 & 7 & 11 & 0.03 & 6 & 5 & 28 \\
\hline MA2 & 13.6 & 1.70 & 53 & 32 & 1.19 & 24 & 34 & 221 \\
\hline TA2 & 6.5 & 0.25 & 43 & 4 & 0.06 & 27 & 15 & 33 \\
\hline
\end{tabular}


Table 5

Simultaneously extracted metals, AVS concentrations in shallows ( $\mathrm{mg} / \mathrm{kg}$ dry weight)

\begin{tabular}{|c|c|c|c|c|c|c|c|c|c|c|}
\hline Sample & As & $\mathrm{Cd}$ & $\mathrm{Cr}$ & $\mathrm{Cu}$ & $\mathrm{Hg}$ & $\mathrm{Ni}$ & $\mathrm{Pb}$ & $\mathrm{Zn}$ & AVS & SEM-AVS \\
\hline 1B & 1.77 & 0.11 & 1.05 & 2.51 & $<0.02$ & 1.08 & 9.75 & 16.17 & 81.8 & -0.27 \\
\hline $1 \mathrm{M}$ & 1.48 & 0.13 & 0.81 & 1.18 & $<0.02$ & 1.25 & 2.16 & 10.15 & 15.2 & -2.20 \\
\hline $2 \mathrm{~B}$ & 1.93 & 0.18 & 1.37 & 2.58 & $<0.02$ & 1.30 & 14.57 & 23.98 & 839.7 & -25.68 \\
\hline $4 B$ & 2.35 & 0.26 & 1.37 & 6.13 & $<0.02$ & 1.02 & 9.65 & 34.47 & 338.9 & -9.88 \\
\hline $8 \mathrm{~B}$ & 4.69 & 1.84 & 1.41 & 8.11 & $<0.02$ & 1.79 & 22.55 & 222.47 & 400.5 & -8.80 \\
\hline $9 \mathrm{~B}$ & 3.02 & 0.97 & 1.15 & 9.22 & $<0.02$ & 1.41 & 15.21 & 94.17 & 95.7 & -1.29 \\
\hline $10 \mathrm{~B}$ & 5.05 & 1.40 & 1.70 & 3.33 & $<0.02$ & 4.19 & 26.21 & 146.94 & 461.8 & -11.89 \\
\hline $11 \mathrm{~B}$ & 1.92 & 0.22 & 0.85 & 5.41 & 0.03 & 4.74 & 9.40 & 24.23 & 28.6 & -0.31 \\
\hline $14 B$ & 2.41 & 0.14 & 0.90 & 4.14 & $<0.02$ & 2.15 & 6.04 & 19.56 & 16.1 & -0.07 \\
\hline $16 B$ & 5.80 & 0.52 & 0.62 & 9.74 & 0.03 & 4.10 & 22.28 & 45.23 & 73.0 & -1.25 \\
\hline $17 \mathrm{~B}$ & 3.28 & 0.28 & 1.18 & 5.66 & 0.03 & 2.93 & 11.64 & 30.63 & 15.5 & 0.18 \\
\hline $19 B$ & 0.66 & 0.10 & 0.64 & 1.86 & $<0.02$ & 0.91 & 3.78 & 11.94 & 30.4 & -0.70 \\
\hline $20 B$ & 1.37 & 0.16 & 1.24 & 5.33 & 0.02 & 2.85 & 8.00 & 21.28 & 11.5 & 0.14 \\
\hline $21 \mathrm{~B}$ & 1.11 & 0.16 & 1.27 & $<0.1$ & $<0.02$ & 1.16 & 7.21 & 16.07 & 180.9 & -5.34 \\
\hline $22 B$ & 2.98 & 0.21 & 1.41 & 5.26 & 0.02 & 1.63 & 8.92 & 61.16 & 286.0 & -7.83 \\
\hline $23 B$ & 2.03 & 0.20 & 1.36 & 5.45 & $<0.02$ & 1.30 & 10.74 & 18.90 & 99.8 & -2.66 \\
\hline $24 B$ & 1.19 & 0.19 & 1.01 & 3.37 & $<0.02$ & 0.95 & 4.50 & 12.68 & 40.9 & -0.99 \\
\hline $25 \mathrm{~B}$ & 0.81 & 0.20 & 1.35 & 2.21 & $<0.02$ & 0.77 & 4.68 & 17.48 & 114.8 & -3.24 \\
\hline $26 B$ & 2.91 & 0.36 & 1.00 & 5.74 & $<0.02$ & 1.39 & 8.73 & 40.18 & 42.7 & -0.56 \\
\hline $27 B$ & 3.15 & 0.46 & 1.38 & 11.01 & $<0.02$ & 1.24 & 10.63 & 46.07 & 6.9 & 0.74 \\
\hline $28 B$ & 3.89 & 2.67 & 2.20 & 29.80 & 0.08 & 1.70 & 32.90 & 738.00 & 407.0 & -0.72 \\
\hline $29 B$ & 2.99 & 0.56 & 1.04 & 6.28 & $<0.02$ & 1.12 & 11.46 & 61.14 & 156.0 & -3.75 \\
\hline $30 \mathrm{~B}$ & 4.73 & 1.43 & 2.64 & 45.21 & $<0.02$ & 3.17 & 34.98 & 192.97 & 493.3 & -11.48 \\
\hline $31 \mathrm{~B}$ & 2.28 & 0.49 & 1.24 & 7.48 & $<0.02$ & 0.71 & 9.87 & 47.02 & 82.8 & -1.68 \\
\hline $32 B$ & 6.37 & 0.68 & 9.76 & 38.51 & $<0.02$ & 8.29 & 47.88 & 153.32 & 243.4 & -4.26 \\
\hline $33 \mathrm{~B}$ & 6.60 & 6.08 & 3.54 & 0.16 & $<0.02$ & 2.25 & 59.80 & 544.10 & 635.0 & -11.10 \\
\hline $34 B$ & 3.32 & 0.27 & 1.23 & 6.72 & $<0.02$ & 2.44 & 7.47 & 40.00 & 4.6 & 0.66 \\
\hline $35 \mathrm{~B}$ & 3.17 & 0.49 & $<0.1$ & 7.16 & 0.05 & 3.66 & 20.50 & 43.20 & 17.6 & 0.39 \\
\hline $36 \mathrm{~B}$ & 2.41 & 0.20 & 1.20 & 7.10 & 0.02 & 3.91 & 7.46 & 21.73 & 3.0 & 0.45 \\
\hline $37 \mathrm{~B}$ & 2.99 & 0.28 & 2.78 & 10.54 & $<0.02$ & 5.46 & 15.88 & 49.11 & 313.6 & -8.69 \\
\hline $\mathrm{SG}$ & 6.03 & 2.32 & 2.56 & 15.62 & $<0.02$ & 2.06 & 42.57 & 470.03 & 9.0 & -18.54 \\
\hline
\end{tabular}

SEM-AVS is reported in $\mu \mathrm{M}$.

among samples were relatively small when results are expressed as PDA: only 2 samples out of 61 showed an effect higher than $30 \%$, even if chemical analyses displayed relatively strong differences in contamination levels (Tables 4 and 5) (MAV-CVN, 1999). Toxicity tests performed with embryos of the sea-urchin Paracentrotus lividus on elutriates extracted from the same sediments showed a strongly marked toxicity difference among the samples: $14(45 \%)$ samples from shallows and 18 $(60 \%)$ samples from channels showed a highly reduced embryo-larval development $(<50 \%$ normal plutei on undiluted elutriate) and were classified as being from medium up to extremely highly toxic samples (Picone, unpublished data). These data highlighted a toxicity distribution closer to that expected from chemical analyses (not shown). Sperm-cell tests on the same samples were not as sensitive as the embryos development test, but could highlight a hot-spot of toxicity in 3 samples. The data obtained with $P$. lividus are in agreement with the results of earlier studies on some of the sites investigated (Losso et al., 2004b; Volpi Ghirardini et al., 2005). Moreover, the 90th percentile of the MSD's found (10) is rather lower than the values reported in the literature for the marine and estuarine amphipods $A$. abdita, E. estuarius and $R$. abronius
(20, 25, and 23, respectively) (Phillips et al., 2001). This lower value was probably due to low among-replicate variation obtained with Venice Lagoon sediments. On the one hand this reveals the good replicability of the test, but on the other it could be an indicator of lower sensitivity. The lower sensitivity of the Corophium genus compared to $R$. abronius and $A$. abdita reported in the literature (Environment Canada, 1992; Bat and Raffaelli, 1998) could be in part explained by different ecological characteristics of $R$. abronius (which is a free-burrowing amphipod directly exposed to pore-water and sediment and not a tube-dweller like Corophium) and the different test-temperature $\left(20^{\circ} \mathrm{C}\right)$ often used when testing sediments with A. abdita (USEPA, 1994; ASTM, 2003). For all the above-mentioned features, when developing the toxicityscore proposed in this paper, we focussed our efforts on providing a tool able to take this lower sensitivity of C. orientale into account (i.e. choice of 90 th percentile multiples). Following this design, even a relatively small deviation from "non-toxicity" conditions leads to the assignation of a higher toxicity judgment. The discriminatory power of this acute test protocol might be enhanced by extending the exposure period (up to 28 days) or shifting the test temperature up to $20^{\circ} \mathrm{C}$. 


\section{Conclusion}

C. orientale exhibits a good discriminatory ability when testing pure substances, although the data confirmed that Corophium are less sensitive than other species. Sediment toxicity test results highlighted the applicability of the method to Venice Lagoon sediments; the tolerance to a wide range of sediment typologies and grain-sizes is a valuable advantage when heterogeneous environments are studied. Moreover, $C$. orientale was very resistant to ammonia, which is one of the most critical confounding factors when testing sediments from highly productive or organic matter-rich ecosystems. The site specific toxicityscore, developed taking into account (1) the variance obtained for every sediment-control pair and (2) the relative sensitivity of $C$. orientale, allowed the samples to be discriminated on the basis of their toxicity, even if the discriminatory power of the test is still of concern. The sediments tested showed very different chemical contamination, which increased from sea-inlets towards the industrial area. Higher mortality was expected in the more polluted sites, especially those in or near the industrial area, whereas there was very little difference in mortality between the supposed control sites (2B, 19B, 22B, 24B) and the others. A comparison with the tests performed on sea-urchin early life stages confirmed the relatively lower discriminatory ability of the $C$. orientale 10 -d mortality test. However, these tests were carried out on a different matrix (elutriate) and the endpoints are well known as being more sensitive than mortality (especially embryo development). Nevertheless, the data obtained displayed acute toxicity towards the autochthonous amphipods only in a few sites located close to the industrial area and in deep sediments from channels, indicating that most of the Lagoon is characterised by sediment which is not toxic toward $C$. orientale in the short-term.

\section{Acknowledgments}

This work was funded by ICSEL project promoted and funded by the Magistrato alle Acque di Venezia (Venice Water Authority) through its concessionaire Consorzio Venezia Nuova and by Thetis S.p.A. The authors are very grateful to Andrea Berton, Anna Carlin, Emiliano Molin and Fabrizio Bernardi-Aubry for sampling sediments. Roberto Cattelan performed total ammonia and TOC content analysis. The contents of this paper are the sole responsibility of the authors and do not represent the position of Consorzio Venezia Nuova. Alison Garside revised English text.

\section{References}

Allen, H.E.F., Deng, G.B., 1993. Analysis of acid-volatile sulfide (AVS) and simultaneously extracted metals (SEM) for the estimation of potential toxicity in aquatic sediments. Environ. Toxicol. Chem. 12 (8), 1441-1453.
Arizzi Novelli, A., Volpi Ghirardini, A., Giuliani, S., Falugi, C., Pagano, G., Iaccarino, M., 2001. Evaluation of coastal water and sediment toxicity towards gametes and embryos from sea urchin using different test procedures. Biol. Mar. Med. 8 (2), 41-59 (in Italian, English abstract).

Arizzi Novelli, A., Argese, E., Tagliapietra, D., Bettiol, C., Volpi Ghirardini, A., 2002. Toxicity of tributyltin and tripheniltin to early life stages of Paracentrotus lividus (Echinodermata: Echinoidea). Environ. Toxicol. Chem. 21, 859-864.

Arizzi Novelli, A., Picone, M., Losso, C., Volpi Ghirardini, A., 2003. Ammonia as confounding factor in toxicity tests with the sea urchin Paracentrotus lividus (Lmk). Toxicol. Environ. Chem. 85 (4-6), 183-191.

Armstrong, D.A., Chippendale, D., Knight, A.W., Colt, J.E., 1978. Interaction of ionized and unionized ammonia on short-term survival and growth of prawn larvae, Macrobrachium rosenbergii. Biol. Bull. $154,15-31$.

ASTM, 2003. Standard test method for measuring the toxicity of sediment-associated contaminants with estuarine and marine amphipods. E1367-03.

Bat, L., Raffaelli, D., 1998. Sediment toxicity testing: a bioassay approach using the amphipod Corophium volutator and the polychaete Arenicola marina. J. Exp. Mar. Biol. Ecol. 226, 217-239.

Bat, L., Raffaelli, D., Marr, I.L., 1998. The accumulation of copper, zinc and cadmium by the amphipod Corophium volutator (Pallas). J. Exp. Mar. Biol. Ecol. 223, 167-184.

Berry, W.J., Hansen, D.J., Mahony, J.D., Robson, D.L., Di Toro, D.M., Shipley, B.P., Rogers, B., Corbin, J.M., Boothman, W.S., 1996. Predicting toxicity of metal-spiked laboratory sediments using acidvolatile sulphide and interstitial water normalizations. Environ. Toxicol. Chem. 15, 2067-2079.

Bigongiari, N., Braida, T., Pasteris, A., 2001. Bioassay with the amphipod Corophium orientale: methods and applications on marine sediments. Biol. Mar. Med. 8 (2), 60-71 (in Italian, English abstract).

Bocci., M., Barbanti, A., Castellani, C., Carafa, R., Carrer, S., Montobbio, L., 2005. An ecosystem approach to contamination of the Lagoon of Venice (Italy). In: Özhan, E. (Ed.), Proceeding of the Seventh International Conference on the Mediterranean Coastal Environment, MEDCOAST 05, 25th-29th October 2005. Kuşadasi, Turkey, pp. 791-802.

Bombardier, M., Bermingham, N., 1999. The sed-tox index: toxicitydirected management tool to assess and rank sediments based on their hazard-concept and application. Environ. Toxicol. Chem. 18, 685-698.

Bryant, V., Newberry, D.M., McLusky, D.S., Campbell, R., 1985. Effect of temperature and salinity on the toxicity of nickel and zinc to two estuarine invertebrates (Corophium volutator, Macoma balthica). Mar. Ecol. Prog. Ser. 24, 139-153.

Carr, R.S., Long, E.R., Windom, H.L., Chapman, D.C., Thursby, G., Sloane, G.M., Wolfe, D.A., 1996. Sediment quality assessment studies of Tampa Bay, Florida. Environ. Toxicol. Chem. 15, 1218-1231.

Carrer, S., Coffaro, G., Bocci, M., Barbanti, A., 2005. Modelling partitioning and distribution of micropollutants in the lagoon of Venice: a first step towards a comprehensive ecotoxicological model. Ecol. Model. 184, 83-101.

Ciarelli, S., Vonck, W.A.P.M.A., van Straalen, N.M., 1997. Reproducibility of spiked-sediment bioassays using the marine benthic amphipod Corophium volutator. Mar. Environ. Res. 43, 329-343.

Di Toro, D.M., Mahony, J.D., Hansen, D.J., Scott, K.J., Hicks, M.B., Mayr, S.M., Redmond, M.S., 1990. Toxicity of cadmium in sediments: the role of acid volatile sulphide. Environ. Toxicol. Chem. 9, 1487-1502.

Environment Canada, 1992. Biological test method: acute test for sediment toxicity using marine or estuarine amphipods. EPS 1/RM/26.

Environment Canada, 1998. Biological test method: reference method for determining acute lethality of sediment to marine and estuarine amphipods. EPS $1 / \mathrm{RM} / 35$.

Erdem, C., Meadows, P.S., 1980. The influence of mercury on the burrowing behaviour of Corophium volutator. Mar. Biol. 56, 233-237. 
Ewell, W.S., Gorsuch, J.W., Kringle, R.O., Robillard, K.A., Spiegel, R.C., 1986. Simultaneous evaluation of the acute effects of chemicals on seven aquatic species. Environ. Toxicol. Chem. 5, 831-840.

Finney, D.J., 1971. Probit Analysis. Cambridge University Press, London, UK.

Gajbhiye, S.N., Hirota, R., 1990. Toxicity of heavy metals to brine shrimp Artemia. J. Indian Fish. Assoc. 20, 43-50.

Hampson, B.L., 1977. Relationship between total ammonia and free ammonia in terrestrial and ocean waters. J. Cons. Int. Explor. Mer. 37, $117-122$.

ICES. International Council for the Exploration of the Sea, 2003. Report of the ICES Advisory Committee on the Marine Environment, 2003. ICES Cooperative Research Report, Copenhagen, 16-20 June 2003.

Ingersoll, C.G., 1995. Sediment tests. In: Rand, G.M. (Ed.), Fundamentals of Aquatic Toxicology. Effects, Environmental Fate, and Risk Assessment, second ed. Taylor \& Francis, Washington, DC, pp. 231-255.

ISO (International Standard Organization), 2005. Water qualitydetermination of acute toxicity of marine or estuarine sediment to amphipods. ISO 16712:2005(E).

Kater, B.J., Hannewijk, A., Postma, J.F., Dubbeldam, M., 2000. Seasonal changes in acute toxicity of cadmium to amphipod Corophium volutator. Environ. Toxicol. Chem. 19, 3032-3035.

Kohn, N.P., Word, J.Q., Niyogi, D.K., 1994. Acute toxicity of ammonia to four species of marine amphipods. Mar. Environ. Res. 38, 1-15.

Lera, S., Macchia, S., Dentone, L., Pellegrini, D., 2004. Variazione della sensibilità al Cd e SDS di due popolazioni di Corophium orientale. Poster presented at XIV S.It.E (Società Italiana Ecologia), 4-6 October 2004, Siena, Italy.

Losso, C., Arizzi Novelli, A., Picone, M., Volpi Ghirardini, A., Ghetti, P.F., Rudelo, D., Ugo, P., 2004a. Sulfide as a confounding factor in toxicity tests with the sea urchin Paracentrotus lividus: comparison with chemical analysis data. Environ. Toxicol. Chem. 23, 396-401.

Losso, C., Arizzi Novelli, A., Picone, M., Marchetto, D., Pessa, G., Molinaroli, E., Ghetti, P.F., Volpi Ghirardini, A., 2004b. Evaluation of surficial sediment toxicity and sediment physico-chemical characteristics of representative sites in the Lagoon of Venice (Italy). J. Marine Syst. 51, 281-292.

MAV-CVN, 1999. Mappatura dell'inquinamento dei fondali lagunari. Final Report. Consorzio Venezia Nuova, Venice, Italy (in Italian).

MAV-CVN, 2003. Attività di Monitoraggio Ambientale della Laguna di Venezia, esecutivo del $1^{\circ}$ stralcio triennale (2000-2003) MELa1, Attività C.3.3. Studio ARTISTA. Final Report, Consorzio Venezia Nuova, Venice, Italy (in Italian).

McGee, B.L., Wright, D.A., Fisher, D.J., 1998. Biotic factors modifying acute toxicity of aqueous cadmium to estuarine amphipod Leptocheirus plumulosus. Arch. Environ. Contam. Toxicol. 34, 34-40.

Meador, J.P., 1993. The effect of laboratory holding on the toxicity response of marine infaunal amphipods to cadmium and tributyltin. J. Exp. Mar. Biol. Ecol. 174, 227-242.

Moore, D.W., Bridges, T.S., Gray, B.R., Duke, B.M., 1997. Risk of ammonia toxicity during sediment bioassays with the estuarine amphipod Leptocheirus plumulosus. Environ. Toxicol. Chem. 16, 1020-1027.

Nendza, M., 2002. Inventory of marine biotest methods for the evaluation of dredged material and sediments. Chemosphere 48, 865-883.
Onorati, F., Volpi Ghirardini, A., 2001. Information supplied by the different matrices analysed with bioassays: the suitability of Vibrio fischeri. Biol. Mar. Med. 8 (2), 31-40 (in Italian, English abstract).

Onorati, F., Bigongiari, N., Pellegrini, D., Giuliani, S., 1999. The suitability of Corophium orientale (Crustacea, Amphipoda) in harbour sediment toxicity bioassessment. Aq. Ecosys. Health Manage. 2, 465-473.

PARCOM, 1995. Protocols on methods for the testing of chemicals used in the offshore industry. Part A: A sediment bioassay using an amphipod Corophium sp. Oslo and Paris Commissions.

Phillips, B., Hunt, J.W., Anderson, B.S., Puckett, H.M., Fairey, R., Wilson, C.J., Tjeerdema, R., 2001. Statistical significance of sediment toxicity test results: threshold values derived by the detectable significance approach. Environ. Toxicol. Chem. 20, 371-373.

Postma, J.F., de Valk, S., Dubbeldam, M., Maas, J.L., Tonkes, M., Schipper, C.A., Kater, B.J., 2002. Confounding factors in bioassays with freshwater and marine organisms. Ecotox. Environ. Saf. 53, 226-237.

Rehwoldt, R., Lasko, L., Shaw, C., Wirhowski, E., 1973. The acute toxicity of some heavy metal ions toward benthic organisms. Bull. Environ. Contam. Toxicol. 10 (5), 291-294.

RIKZ, 1999. Standard operating procedure Nr. Species - 01 marine amphipod Corophium volutator mortality sediment toxicity test. Riijksinstituut voor Kunst en Zee, RIKZ/AB-99.114x, The Netherlands.

Shepard, F.P., 1954. Nomenclature based on sand-silt-clay ratios. J. Sed. Petr. 24, 151-158.

Solarzano, L., 1969. Determination of ammonia in natural waters by the phenol-hypochlorite method. Limnol. Oceanogr. 14, 799-801.

Tabata, K., 1962. Toxicity of ammonia to aquatic animals with reference to the effect of $\mathrm{pH}$ and carbonic acid. Tokai-ku Suisan Kenkyusho Kenkyu Hokoku 34, 67-74 (English translation).

Thursby, G.B., Heltshe, J., Scott, K.J., 1997. Revised approach to toxicity test acceptability criteria using a statistical performance assessment. Environ. Toxicol. Chem. 16, 1322-1329.

USEPA, 1992. Chesapeake Bay program. Development of a chronic sediment toxicity test for marine benthic amphipods. EPA 903/R-92/ 002.

USEPA, 1994. Methods for assessing the toxicity of sediment-associated contaminated with estuarine and marine amphipods. EPA 600/R-94/ 025.

USEPA, 2001. Method for assessing the chronic toxicity of marine and estuarine sediment-associated contaminants with the amphipod Leptocheirus plumulosus. EPA 600/R-01/020.

USEPA, 2002. Short-term methods for estimating the chronic toxicity of effluents and receiving waters to marine and estuarine organisms, third ed., October 2002. EPA 821/R-02/014.

Volpi Ghirardini, A., Arizzi Novelli, A., Tagliapietra, D., 2005. Sediment toxicity assessment in the Lagoon of Venice (Italy) using Paracentrotus lividus (Echinodermata: Echinoidea) fertilization and embryo bioassays. Environ. Internat. 31, 1065-1077.

Whitfield, M., 1974. The hydrolysis of ammonia ions in sea water-a theoretical study. J. Mar. Biol. Assoc. UK 54, 565-580.

Wright, D.A., Frain, J.W., 1981. Cadmium toxicity in Marinogammarus obtusatus: effect of external calcium. Environ. Res. 24, 338-344. 